Excerpt rrom report COLD LODES OF TYE INENANA DISTRICT by Earl R. Pllgrim, Associate 11 ing inglneer for Territorial Department of Minea - March 10, 1933

\title{
Eva Creek
}

In July 1915 Peter Swanson and John Montan discovered a body of mineralized schist outcropplng on Eva Creek tributary of Elsie Creek and Callfornia Creek. The property was optloned to a spokane group and considerable work vas done on It in 1924 and 1925. A 12 mile automobile roed wes constmucted by the Territory, to the property in 1925, but through disagreement over terms, work was stopped on the property and it remalned 1dle unt1l in 1930 when a lease was taken by Nlgot Norbert, Oscar F. Erickson, Justice Johnson and Bror Johnson. The property known as the Liberty Beil Mine consisto of the following cleims:

$\begin{array}{ll}\text { Liberty Bell } & \text { Bear Paw } \\ \text { Liberty Bell Fraction } & \text { Bose } \\ \text { Liberty Bell No. } 3 & \text { Irene Fraction } \\ \text { Liberty Bell No. } 4 & \text { Irene No. } 2 \\ \text { W1ld Goose } & \text { Four above Placer Clalm }\end{array}$

The comp, located on the Itberty Bell No. 4 claim $1 \mathrm{~s}$ at an elevation of 2,545 peet. The claims 11 e across the valley of Eva Creek and extend onto the hillside south of the creek.

The underground workings conaigt of a vertlcal shaft sunk from a point cloge to the south edge of the creek, for a diatance of about 70 feet. The shaft encounters the mineralization at a depth of about 20 feet. A tunnel is driven from the edge of the creek for a distance of about 550 Peet whth 3 cross drifts tc the south, 170 feet, 130 feet, and 20 feet. In length. From the latter whlch starts from a point 100 feet 10, a winze hs been suak 30 feet and a drift from the bottom driven to the south for a distance of 140 feet following the minerallzation. Most of these workings have caved and are at present 1naccessible. A new tunnel has been drtven Prom a polnt 50 leet northeast of the origiral tunnel, at an elevation of 2,492 feet in a direction of 8 . $5 \frac{10}{2} \mathrm{~W}$. for a distance of 260 feet. A cross-drift $1 \mathrm{~s}$ turned of to the northwest from a polnt 70 feet in, for a distance of 175 leet. At a polat 60 leet farther in the tunnel, a crosi-drift is driven to the southeast for 135 feet where a fault is encountered which drops the formation to the east for over 30 feet vert1cally. The intnerallzation oocurs in a black elate lylug Pran horizontal to $30^{\circ} \mathrm{W}$ and extends downward from a hard rather Irmerplous bed of quartzite overlytag the slate. Most of the prospecting has boen done by driving the tunuels with cross-drifts axtended off to elther side. It was found Impossible to keep the minerallaed rone next to the roof in the tunnels and crose-drifts for considerabie distances due to the upward or downward slope of the beds. Ralses were driven at intervals to cross the ore zone and also winzes were sunix occasionally whon the slate dipped below the drifts. Nbout 400 feet east of the new tunnel and downstream, a tunnel is oriven in a southerly direction for 50 feet. A ininze is sunk from there to a depth of 10 feet and a drift drtiven 22 feet to where $1 t$ encountered a fault. 200 feet 
southeast of this tunnel is a short tunnel at an elevation of 2,504 feet, 55 feet in length, driven in a, southwesterly direction. A winze is sunk from the face, the depth of which 18 not known. About 1, 250 feet east of the new tunnel, on the south side of the creek, at an elevation of 2,450 feet, on the Irene clatm, a tunnel has been driven $\mathrm{S}$. $24^{\circ} \mathrm{W}$. for 25 leet. This tunnel is sald to show gome valueg. A drill hole sunis from Just below the portal of the tunnel to a depth of 17 feet is sald to show an average of $\$ 4.80$ in cold and silver.

The mineralization consists of quartz, arzenopycite, blamuthInIte, Dyrite, gold and s1lver. Some native blsmuth has been noted but was not observed by the writer. The mineralization extends from the quartzite roof cownward with the best values in gold and aliver appareatily close to the roof. The arsenopyrite and blsmuthinfte although assoclated with the gold generally, do not always accompany the best gold vel ues. One sample taken by the writer assayed: gold $4.02 \mathrm{oz}$., silver $0.20 \mathrm{oz}$, arsenic $0.85 \%$, bismuth $0.32 \%$. Another sample returned: gold $26.80 \mathrm{oz}$, sliver 1 oz., arsenic 21.25\%, blsmuth 5.52\%; whlle a thlrd sample showed: gold 0.56 oz., silver $0.10 \mathrm{oz}$, argenlc $19.75 \%$, and bismuth 3.37\%. These indicate little close relationshlp between the gold, arsenopyrite, and b1emuthinite and a probsb111ty that careful metallurgy w111 be able to separate the cold from the sulphides without cyanldation, or having to ship a concentrate. The property is in a very accessible location for operating. Excellent timber is avallable about 6 miles diatant on Californta Creek. A number of cosl seama are located on California and Bonanza Creeks. One seam outcropplng in a side gulch on the esit side of Calfornia Creek, has been opened up by the lessees of the Liberty Bell property. Th1s seam showing 17 feet in thickness, is described by Martin: "ixposure No. 30. In the same sulch at an altitude of 1,985 feet is a coal bed 17 leet thick, which strikes N. $60^{\circ} \mathrm{E}$ and dipa 15\%." Above this seam are two other seams described by Martin: "Exposure No. 28. In a gulch in the NE $\frac{1}{4}$ sec 27 , at an altitude of 2,045 leet, $1 \mathrm{~s}$ a coas. bed 6 feet talck, with a vartable clay stiringer. Th1s bed strikes IR. $65^{\circ} \mathrm{E}$. and dips $45^{\circ} \mathrm{S."} \mathrm{"Exposure} \mathrm{Mo.} \mathrm{29.} \mathrm{In}$ the same gulch at an altitude of 2,020 feet a coal bed 8 feet thlck atrikes $\mathrm{N} .85^{\circ} \mathrm{W}$. and dips $40^{\circ} \mathrm{S}$. (?)"

Above copy made in the Territorial Department of Mines Juneau Offlce on October 3, 1957 
Gode Jodes of me lienana Jistrict.

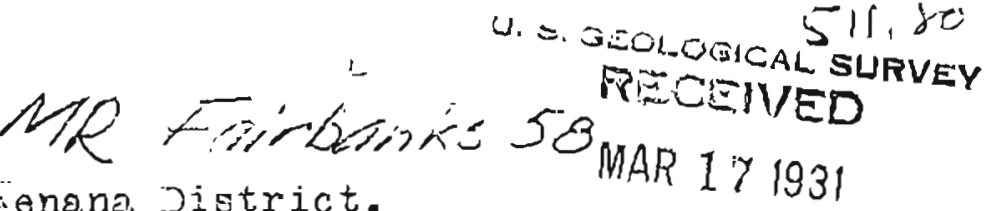

Introduction.

$\therefore ;$

The purpose of this report is to ciescribe the occurrence of lode gold in that section north of the ilaska Sange, whjor has been previously described as the western yart of the Bonnifield Region and as a part of the ienana coal irield b iveither of theoe publications cover the Gold lode deposiths described in this report. Data for this report vere obtoined during a number of visits to the region in 1924, 1925, 1926, 1927, and in iebruary 1931.

\section{Geography .}

The Nenano diatrict covers the area in the northern foothills of the Alaska Range, jetween the range and the Tanana Valley and extending both east and west of the Nenana River. It is a resion of moderate relief, ransing in elevation from 1,000 feet to orer 4,000 feet in elevation. The hillg generally trend in an east-prest direction with long smooth rounded crests. The deainage is north to the Tanana Valley and east and rest to the Nenana River. The principal north flowing streams, named from west to east, are the Nenana Riter, Totatlanika, Tatlanika, and Gold King'creeks and Wood River. The vest flowing streams are Iignite, Healy, and roody crecks. The Nenana River the largest stream of the region, heads on the south side of the Alaska Range, cutting a broad pass bhrough the range and foothills to the Tanana Valley. It heads in glaciers, as do a numoer of its tributaries, cutting a deep narrow canyon through the range folloved by a characteristic glacial gravel filled flat valiey floor on lts courge through the region here described. The low pass formed by this river is utilized by the Alaska Railroad in crossing the Alaske Range.

Wood River is the only other stream in this region, which is fed from glaciers. The other streame are clear gater confined to narrow

a. The Bonnifield Region, Stephen R. Capis, U. S. G. S. No. 501, 1912. b. The Nenana Coal Field, G. C. Ktartin, U. S. G. S. iio. 664, 1919 \& 


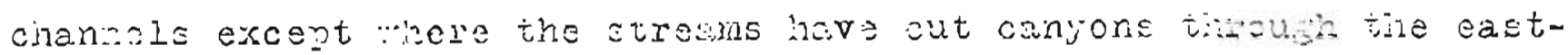
nest ridgos leavinij mide sacins oet:ietn.

\section{Clineto.}

The climete of the itenana district is continental, characterized by ereat extremes in iemerature oi the scasons and by 2 light precipitation. Records have not been sept in the inudediate vicinity out the temperatures are known to be decidedly higher in rinter than at a few miles farther north at lower elevations, in the Tanana Valley. Also the annual sno:rfall is ruch less than in the lower Interior points. liuch of the resion is nearly oare of snow ruost uinters, with an accuralation of s. Foot or more in the valleys. nine sumrer seasons are chalacterized by wany clear daye ":ith mocierate temperatures.

\section{Timber.}

Spruce timber is iound along nost of the wider valleys to altitudes of sifintly over 2,000 feet, with the vest timber considerably lomer. Trees up to 24 inches in dianeter at the oase suitable for sar logs, are found in the basins of Rex, Jonanza, Patlanika, Totatlinjka, Gold iing̈, 3onnifield creeks and on iienana and ilood rivers. A large portion of the timber along the east side or iJenana Valley has been burned off. There would not be ovel a fev ulles of haul to secure mining timbers for any section ô the region. .

Game.

The region is one fairly plentiful in eame for the prospeotor: Mountain. oheep are found in the higher mountains $\bar{d}$ few miles to the south. Caribou aften ore tound in the higher valieys in sumor and alon: the barer ridges in winter. loose are found in the lover valleye in winter and sumer. 3lack bear are found in the region ahile the glacier varisty of the grizzly is round ijuther eouth in the hioher mountains. Greying and trout are abundant in the clear streams.

\section{Transportation.}

The Alaska railroad serves the district. Ferry station at mile 371, from sevard, connects $\because$ ith a 12 mile. Ierritorial highway extend- 


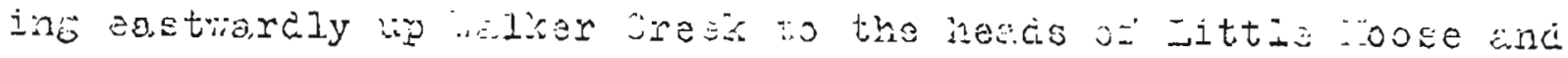

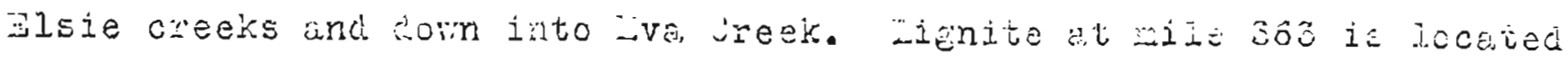

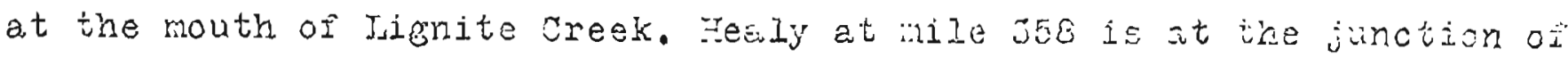

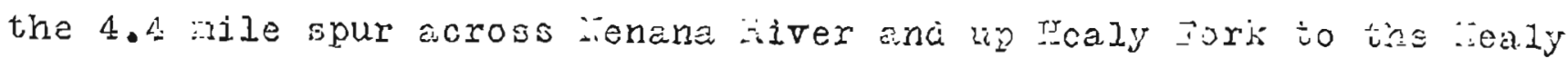
Ziver coal mines e.t suntrara.

$$
\text { Geol.ogr. }
$$

The general ieology or the district has been degcribed clearIy oy Capps. The oldest rocks are a series of metarorphosed secipents known as the Birch Jreek schist and correlated aith tine orest reries of sbhists of the same name underlying large areas or the Interior. These quartz and mica schiste, juartzites, wnc phylites oreatly altered, folded, and intruded have been assigned provisionaliy as pre-Ordovocian. Theyare probably underlying the whole district except there intruded by laree igneous masses, and are outcroping in the hisher areas. Theriorm the high north slope of the silaska.. range.

Overlying these older schists and forming most of the foothills north of́ the range is a series of quartz-ieldopar rocks conEiderably metamorphosed, known as the lotatlanika schist. These rocks grade from gravel and shale eediments near the base to extrusive rolcanics near the top rith the two very much intermixed in detween. The series is freatly alterea and bears considerable resenplance to the older schiste except for the predominance of the valcanics, principally rhyolites. These rocks have been asstenea by capos provisionaliy as silurian or Deronian age.

The next younger rocks lying unconiormably on the Dotatlanika schist and in locelities directly upon the 3irch creek schist sre a series of sandstones, shales, and conglomerates with lignite coal beds. A full description or these lignite coal oeds ras oeen jiven oy hiartin.

A widesgread series of high eravels, sands, and clays is found occupying many of the higher ridges and hills of this region. These sediments at one time undoubtedly covered most of the area but erosion has cut down through, rewashing them until they are completely 


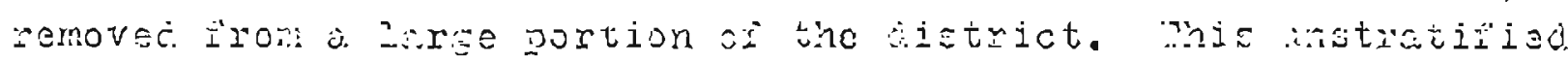

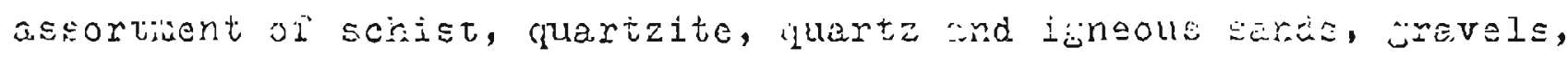
anc claye are velieve: to be the source ji $\ddot{z}$ concicierejle portion

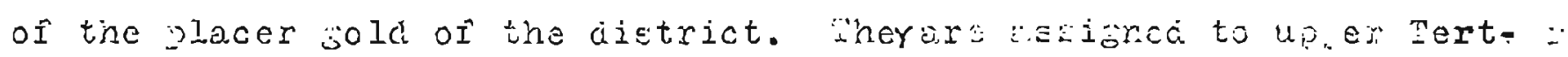
lary (jilocene or Fliocene).

The Guaternary deposites occupyine the streac vileys are till, and present stream seàiments. These cieposites ara unconsolidateh and in many jlaces are being reworked as evidenced by the terraces shown alons the cravel walls of moot oi the vil:ays.

Intruding the 3irch vreek schist and in a rew locelities the 'otatlanika sohist are Granodiorites, diorites, ens snciesites rith smalies dikee or diabase.

Ufineris Rezources.

Gold Flacers.

Flacer 3016 has been found in nearly a.11 of the ctreain eravele

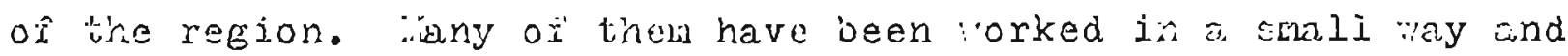
the enonifield wejion recoras o. production or̈ over 300,000 doliars. rost of these plaaers have been previously described End "̈ill not be coversis in this report.

\section{Gold Lodes.}

Gold lodes have besn described by Capys on Chute oreek a tributary of Vood River irom the east and on hansas ureek tributary of "lood iiver. The shute rreek lode is cescribed as "an altered rhyolite gorphyry which meathers to conspicuous red and yellow colors and is illed fith extremely small cubes of finely disseminated pyrite......... The mineralization was ooserved to occur in a zone which has a ridth of over 100 feet, striking nearly north and south, and which has a high dip, ro that a lorse body of byritic rock is exposed. It is renorted thet the uverage values recovered rere equal to $\because 5$ in iree goid to the ton or rock ailled, and thet assays of the tailing's yielded about " more!"

$$
\text { Daniels creek. } k^{+50.109}
$$

A sample furnished the rriter by otto Lindfelder, of o vein uncovered on Daniels Creek tributary of Totatlanika Creek, about 6 


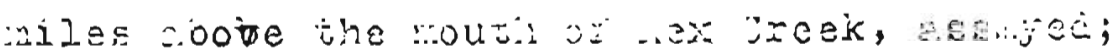

rold -

mis samide "as taiken zrom a guartz vein ceveral inches thiok shoving in the bec. ö an opencut placer.

$$
\text { jíoose vreek. } 2+58 \cdot 1,
$$

i.j. Charles zilkie on upjer Looge sreek has jone s small chount of "ark on a quertz vein outcropine on the south sice oi the creek, It is said to contin some vines in gola ind ilver.

On hoose Grees about 3 miles above its mouth, e ilike or rioa-

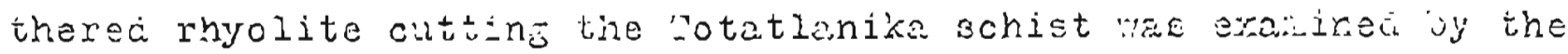
writer in 1925. This dike showed consideraile jyrite mine:sization and a sample taken for assay showed;

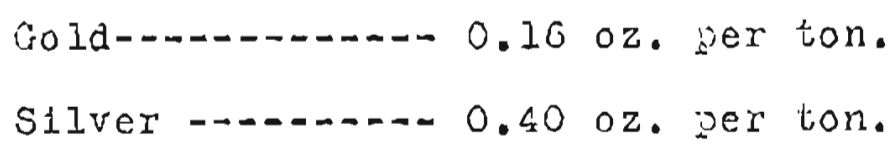

The mineralization apseare to extend ocross a nidtin ut only a fer i eot.

About 2 miles unstrem from this point and at the lover end of a placer cut, a rib of quartzite schist striking east and ciojing to the north, outcrons showing a considerable arsenopyrite mineralization. A somple taken from this outcrop assayed;

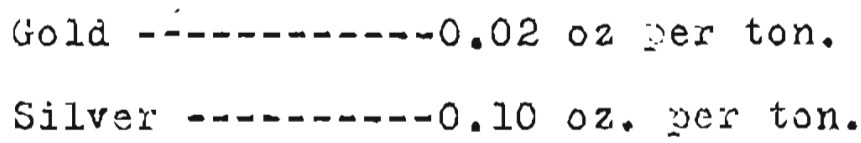

Occasional placer silver nugïets have oesn found in the rravel: of foose Creek.

$$
\text { Zra. Ireek. } k+5^{-53}
$$

In July 1915 Feter Srenson and John wontan discovered a body

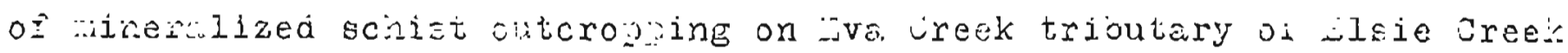
and California ureek. The rroperty was optioned to E Spokane. s:oup and consiaerable work ats done on it in 1924 and 1925 . A 12 inile automobile road was constructed by the l'erritory, to line rroperty in 1925, but throubh cisaresment over terms, :ork :as stopyed on the and $i t$ property $\wedge$ remained idle until in 1930 when a lease was taken oy rigot 


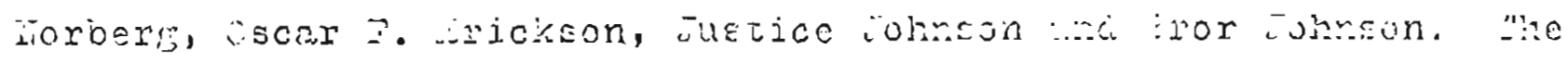

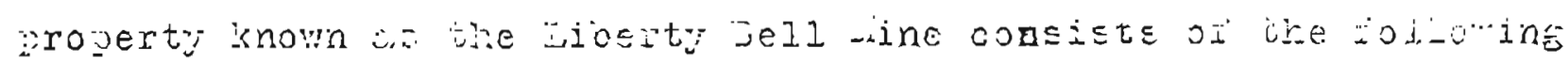
clairss;

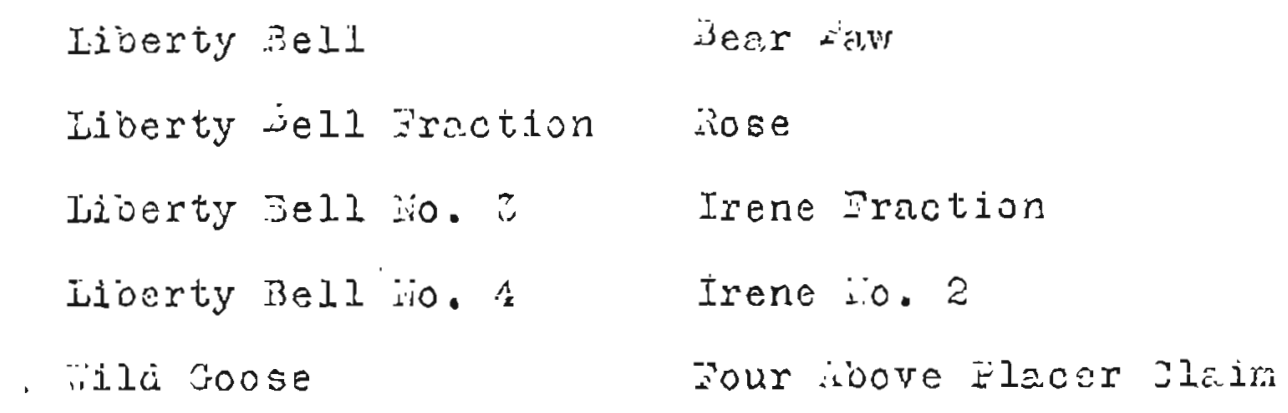

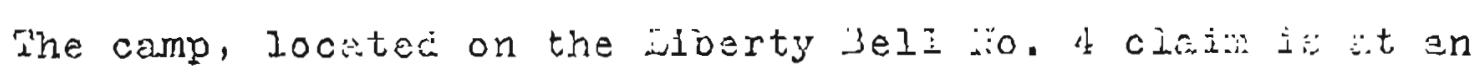

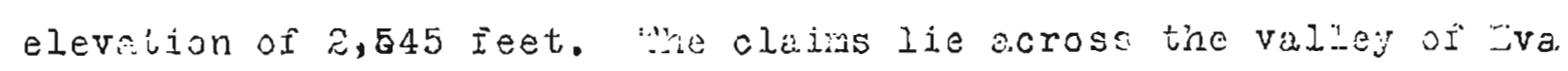
Uress ind extenô onto the hillside south of the creak.

The undersround working coneist or is vertical chalt ounk from a yoint close to the south odse of the creek, for 2 distance of about 70 ieet. The shit encountero the minelalization et a depth of about ro ieet. A tunne is driven from the edge of the creek for a distance or about 550 ieet with 3 cross drifts to the south, 170 reet, 130 feet, and 20 reet in length. From the latter :.hich starts from a point 100 feet in, a vinze has been sunk io feet and a drift from ine sottom ciniven to the south ror a distance of lis reat rollow ine the minerslizotion. Fost of these rokkings have caved and ore at present inaccessaole. A riew tunnel has oeen driven lrom ä joint 50 feat northeast of the origionol tunnel, nt an elevation or 2,492 feet

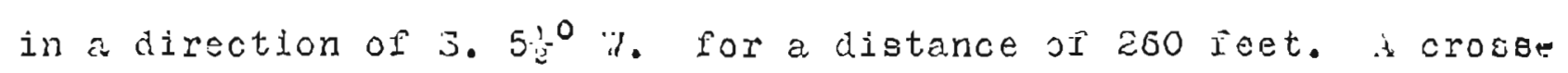
drift j.s turned of to the northwest from a point 70 feet in, for a distance of 175 feet. At a point oo feet rarther in the tunnel, a cross-drift is driven to ihe southeast For 135 seet whers c iault is encountersd wich srope the rornation to the east for over zo feet vertically. The mineralization occurs in s. olack slate lyinf irom

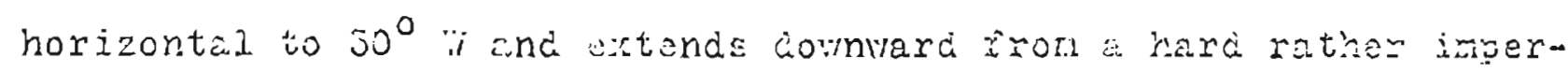
vious bed of quartzite overlying the slate. rost or the sropecting has been cione by drivinc the iunnels rith crose-drifts extencied orf to either gide. It ras Found imposible to kep the minerelized zone next to the roof in the tunnels and crosi-crittts lior considerable distances due to the upvard or downvard blope of the oeds. Raises 


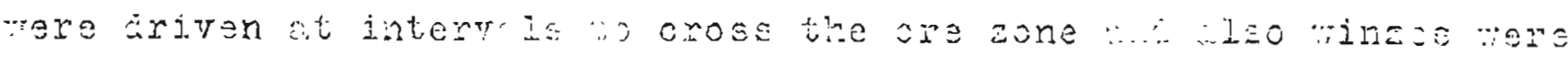

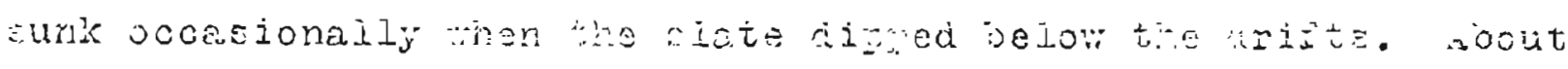
too feet east or the new tunnel and downstream, : wnnel ja ariven in a southernig direction for ô iset. Arinze is gunk froritione to $c$

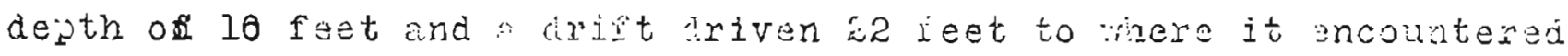
a ialt. 200 feet southesit or this tunnol is is short tunreI at in elevation of 2,504 feet, 55 foat in length, driven in a soutruestarnly direction. A winze is sunk rrom the face, the depth oi wich is not knom. About 1,250 feet east of the ner tunnel, on the couth side of the creek, at an elevation of 2,450 ieet, on tha irene clain, a tunnel has been driten $S$. E.4 $\%$ for 25 feet. ihis tunnel is soid to show sone values. A drill hole sunk from just below the jortei of the tunnel to a depth or 17 feet is seis to sho: sn everage or 4.30 in srold and silver.

The mineralization consists of quattz, areenopyrite, bismuthinite, pyrite, gola anc silver. Some natibe bismuth has oeen noted but was not observed oy the writer. The minerolization extends trom the quartaite roof downvard with the oest values in gold and silver apparantly close to the roof. The arsenopyrite ansi bismthinite although associated $\because$ ith the gold jenerally, do not al ays accompany the beat gold values. One somple taken by the writer assayed; gold 4.02 oz., silver 0.20 oz., arsenic $0.85 \%$ of., bisruth $0.32 \%$ Another

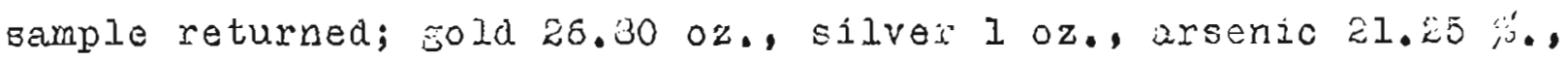
oismuth $5.52 \mathrm{~m}$, while a third sample shored, gold 0.56 oz., silver $0.10 \mathrm{oz}$, arsenic $19.75 \%$ and bismuth $3.37 \%$ These indirate little close relationship betwe n the cold, arsenopyrite, and bismuthinite and a probability that careful metallurgy rill be able to seperate the cold from the sulphides mithout cyanadation, or having to ship a concentrate. The property is in a very accescable location for operatins. ixxcelient timber is available aoout c riles distent on California Creek. A number of coal seams are located on jalifornia and Bonanza creeks. One sear outcropzing in asde sulch on the east side of California creek, has been opened up by the Jessees of the Liberty Bell property. This seam showing 17 feet in thickness, is 


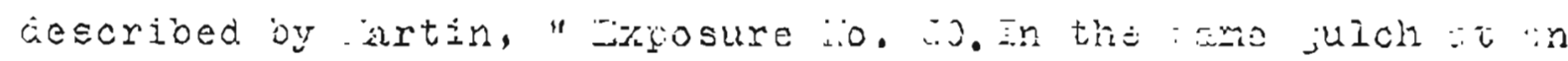
altitudo of I, 385 yet ia T. $30^{\circ}$ i. and aijs $15^{\circ} \mathrm{S} . "$ doove this sean sre tro other soams described oy igrtin, "zxoosure zo. 28. In a julch in the $i=.2$ gac 27, at an cltitude of 2,045 i eet, is coal jed 5 feet thick, :ith a variable clay stringer. Jhis bed strikes $2 ., 55^{\circ} 3$ and jiযs $45^{\circ}$ S." "Ixposure 30.29 . In the sarne julch at isn altitude or̈ 2,020 Ieet a coal beil 3 feet thick strikes $i .35^{\circ}$ i. snd dips $40^{\circ} \mathrm{s}$. (?)" Little roose cresk. $58 / 1$ !

it the ine af Iittle joose Jreek near the divide jatroen

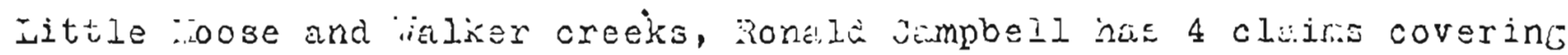
a jola silver nineralization in sohist. is numer or pits hive been dug on several outcrops and one short turnel 18 feet in lensth at an elevation of $\ddot{a}, 444$ feet ixiven in a direction of $i .70^{\circ} 3$. on the east side of the north iork of Little : in $\rightarrow$ light colored clayey schist (probaly an altered rhyolite) dipning $24^{\circ} \mathrm{JE}$. and stricing $\mathrm{H}$. $25^{\circ} \mathrm{F}$. The schist is said to carry fid fair values in iree cold.

Respectfully Subnitied,
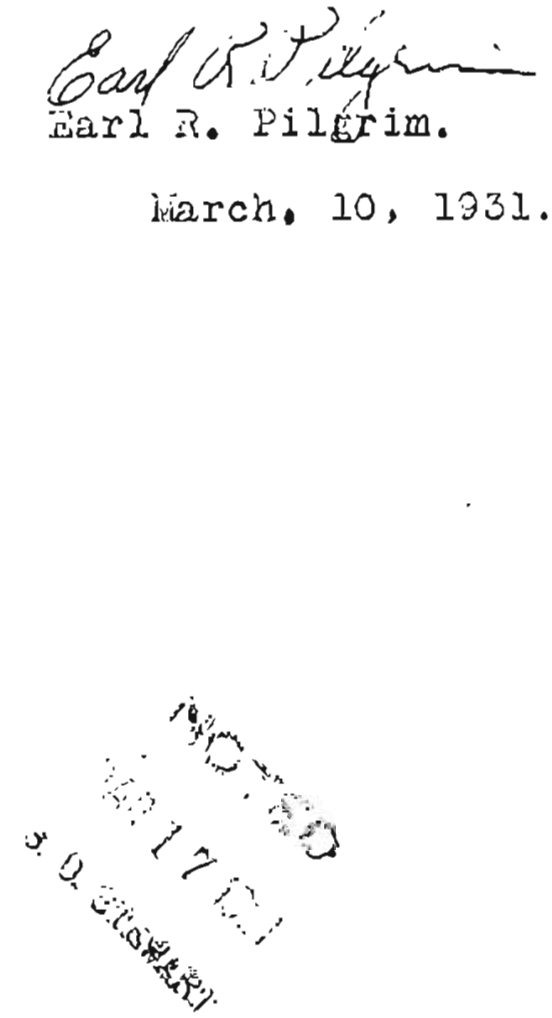


\section{Alaska Agricultural Cunege and School of Mines}

In Cooperation with

U. S. Bureau of Mines, Department of Commerce
College, Alaska

Feb, 13, 1931.

REPORT OF A.SSAY

Mr. R. R. P1igrin, Territorlal Mining Eng1noer, Falrianks.

On samples received from

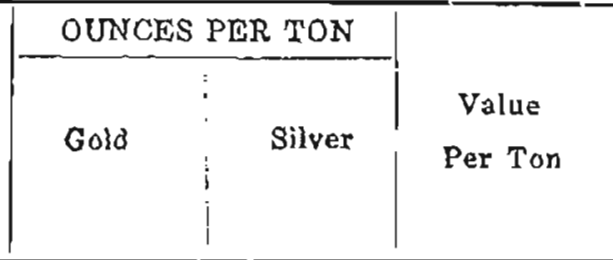

PERCENTAGE OF
Arsen10: B1 smuth $\left|\begin{array}{l}\text { doidity } \\ \text { (Ibs. Cad Iron } \\ \text { per ton) }\end{array}\right|$

01166

01167

01168

01269

01270

01171

01172

01173

01174

01175

01176
Mark on Sampla

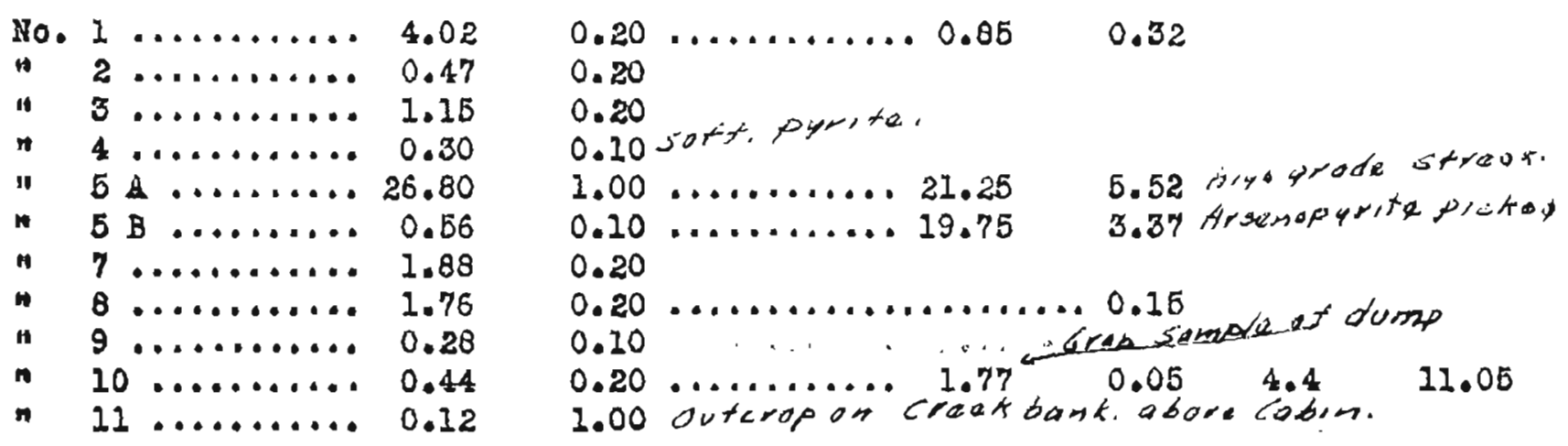

sample \#4 was reosived in the form of ooarge sand consigting of about one third pyrito, the balanoe bolne malnly quartz. No arsenio or blamuth minerals wero sound.

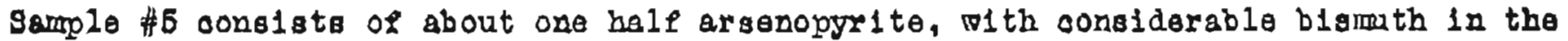
for of blamuthinito, the sulphide. The gangue appears to be quartz and achist.

Sample HE 1 is aimilar to \#5 A exsopt that the gangue is mainly quartz and the oryetels op bismathinite eppear to be larger. $t$

No ooppor, lead or glno was found in any of thege samples. Native bigmuth and netire arsento hare beon found in alratlar ores erom the same property, but nol ther wore found in these gamples.

Loidlty as hlgh as $28 \mathrm{lbs}$. CaO per ton has been found on ore from thls property but this was found in an ore oontala1ng muoh more sulphtdes than sample tio. $4879 \sim 81$

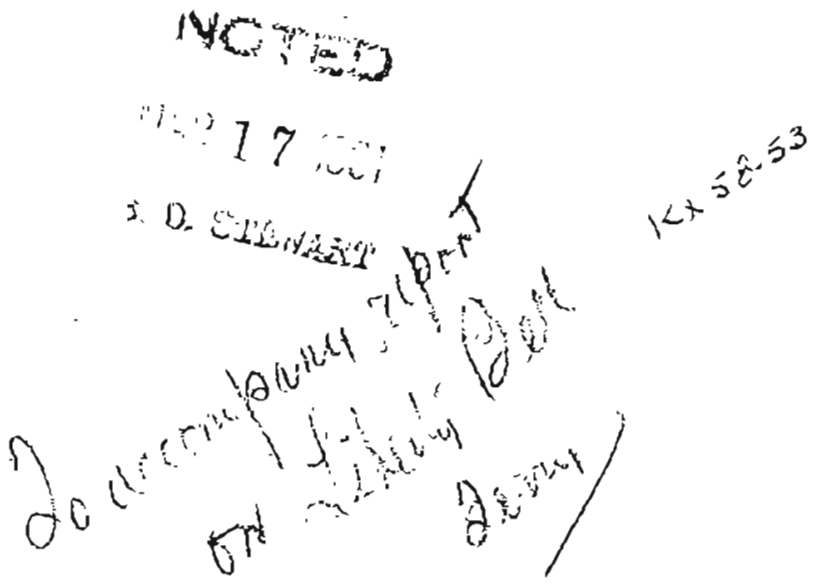
seseged by.

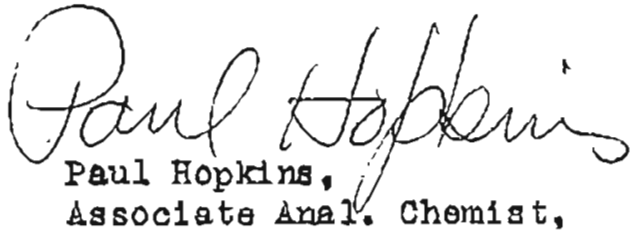

U. S. Bureau of uines.

Total charges for above assays. Offlcial. Amount received from sender. 